\title{
Opportunities to Apply Precision Livestock Management on Rangelands
}

\author{
Derek W. Bailey ${ }^{1 *}$, Mark G. Trotter ${ }^{2}$, Colin Tobin ${ }^{1}$ and Milt G. Thomas ${ }^{3}$ \\ ${ }^{1}$ Animal and Range Sciences, New Mexico State University, Las Cruces, NM, United States, ${ }^{2}$ Institute for Future Farming \\ Systems, Central Queensland University, Rockhampton, QLD, Australia, ${ }^{3}$ Animal Sciences Department, Colorado State \\ University, Fort Collins, CO, United States
}

OPEN ACCESS

Edited by: Pablo Gregorini,

Lincoln University, New Zealand

Reviewed by:

Timothy DelCurto,

Montana State University,

United States

Martín Jaurena,

National Institute for Agricultural

Research (INIA), Uruguay

${ }^{*}$ Correspondence:

Derek W. Bailey

dwbailey@nmsu.edu

Specialty section:

This article was submitted to Agroecology and Ecosystem Services, a section of the journal

Frontiers in Sustainable Food Systems

Received: 29 September 2020

Accepted: 09 March 2021

Published: 15 April 2021

Citation:

Bailey DW, Trotter MG, Tobin C and Thomas MG (2021) Opportunities to

Apply Precision Livestock Management on Rangelands.

Front. Sustain. Food Syst. 5:611915.

doi: 10.3389/fsufs.2021.611915
Precision livestock management has become a new field of study as the result of recent advancements in real-time global positioning system (GPS) tracking, accelerometer and other sensor technologies. Real-time tracking and accelerometer monitoring has the potential to remotely detect livestock disease, animal well-being and grazing distribution issues and notify ranchers and graziers so that they can respond as soon as possible. On-going research has shown that accelerometers can remotely monitor livestock behavior and detect activity changes that are associated with disease and parturition. GPS tracking can also detect parturition by monitoring the distance between a ewe and the remainder of the flock. Tracking also has the potential to detect water system failures. Combinations of GPS tracking and accelerometer monitoring may be more accurate than either device used by itself. Real-time GPS tracking can identify when livestock congregate in environmental sensitive areas which may allow managers the chance to respond before resource degradation occurs. Identification of genetic markers associated with terrain use, decreased cost of GPS tracking and novel tracking data processing should facilitate development of tools needed for genetic selection for cattle grazing distribution. Precision livestock management has potential to improve welfare of livestock grazing rangelands and forested lands, reduce labor costs and improve ranch profitability and improve the condition and sustainability of riparian areas and other environmental sensitive areas on grazing lands around the world.

Keywords: GPS tracking, well- being, grazing distribution, disease, accelerometer

\section{INTRODUCTION}

Livestock operations that rely on rangelands and forested lands differ from intensive operations. Rangelands are typically dominated by grasses and shrubs and occur in non-forested areas that are not suited for farming because limited precipitation and/or tillage is not feasible because of soils or rugged terrain (Lund, 2007; Reeves and Mitchell, 2011). Pastures are often expansive because forage of semi-arid and arid rangelands and forested lands is limited and animals require extensive areas so that they can harvest sufficient forage to be productive. In contrast to intensive operations that house their livestock in barns, pens and small pastures, managers of rangeland livestock operations have difficulty regularly observing their animals (Bailey, 2016). Rangeland livestock operations often use rugged and mountainous terrain with extensive pastures, which limits their ability find and visually observe their animals. Checking the health and well-being 
of livestock grazing rangelands and forested lands is time consuming, and frequent observation of all the livestock is often not practical and sometime not feasible (Bailey, 2016). The goal of precision livestock management is to provide a real-time monitoring and management system that can improve livestock productivity and welfare. Achieving these goals sustains the operation and allows the farmer or rancher to respond as soon as possible (Berckmans, 2014). For rangeland and forest land livestock operations, precision livestock management may be more beneficial than on intensive operations.

Livestock distribution is one of the four principles of grazing management (Vallentine, 2000), and manipulation of livestock movement patterns is a critical factor for sustainable use of grazing lands by livestock (Bailey, 2004). Managers must monitor the spatial use of rangelands and forested lands by livestock to ensure that areas that are preferred by livestock are not overgrazed (Anderson and Currier, 1973). For example, cattle typically spend a disproportionate time in riparian areas, and this concentrated use can lead to damage to stream banks, fishery habitat degradation and lower water quality (Kauffman and Krueger, 1984; Swanson et al., 2015). Managers have numerous tools to manipulate livestock distribution and resolve concerns of concentrated grazing in riparian areas and other sensitive sites including water developments, fencing, strategic supplement placement, herding, timing of grazing, and use of adapted animals (Williams, 1954; Leonard et al., 1997; Bailey, 2005). Riparian areas often make up a small percentage of semi-arid and mountainous rangelands and forested lands, and excessive forage utilization levels and trampling can occur quickly if managers do not intervene and promptly address undesirable distribution patterns (Wyman et al., 2006). However, the extensive nature of rangeland pastures, woody vegetation, and rugged terrain makes it difficult, time consuming and expensive to visually observe and monitor cattle grazing patterns, especially on a regular basis (Bailey, 2016; Bailey et al., 2018). With the promise of real time or near real time tracking (Bailey et al., 2018), ranchers and graziers can apply precision livestock management to mitigate undesirable grazing distribution and concentrated grazing in riparian areas as well as increase uniformity of grazing in extensive pastures and mountainous topography to improve the efficiency of forage harvest (Bailey et al., 2017). Global positioning systems (GPS) tracking can remotely monitor livestock grazing patterns (Turner et al., 2000), and opposed to store on board (SOB) technology real time tracking can inform managers of grazing distribution concerns as they occur so that they can address the issue as it occurs (Trotter et al., 2010).

The goal of this paper is to describe the potential of precision livestock management to improve livestock welfare and help maintain and enhance rangeland health and sustainability. More specifically, our objectives: are (1) to show how GPS tracking, accelerometers and other sensors to remotely detect livestock disease and other animal wellbeing concerns; (2) discuss the value of monitoring livestock grazing patterns in real time or near real time with GPS tracking and accelerometers to help prevent degradation of riparian areas and other habitats, and (3) describe how data collected from GPS tracking and other sensors must be condensed, transmitted, processed, evaluated and transferred to ranchers and graziers so that they can use these technologies in their day-to-day decision making and management.

\section{Detection of Livestock Welfare Concerns}

When livestock become ill, injured, or stressed their day-today behavior changes. Animals have predictable diurnal behavior patterns that can be monitored and quantified (Gregorini, 2012). Studies evaluating cattle activity patterns typically show relatively consistent time allocations to given behaviors, but the time spent grazing and in other behaviors can vary from site to site and across seasons. In yearlong studies, Herbel and Nelson (1966) reported that cattle spent 39 to $46 \%$ of their time grazing on Chihuahaun Desert rangelands, and Schlecht et al. (2004) found that cows in Germany spent $54-67 \%$ of their time grazing. In an Australian study, Kilgour et al. (2012) found that grazing patterns of beef steers varied among five properties within a $140 \mathrm{~km}$ diameter area of New South Wales. Behavior patterns can also vary among animals. Gary et al. (1970) observed that cows in the same pasture could have different grazing patterns. To detect changes in behavior patterns associated with disease and other welfare concerns, evaluations of normal vs. abnormal should ideally be conducted on the same animal or at least among contemporaries of animals managed together in the same pasture. For example, current behavior could be compared to diurnal behavior patterns that occurred in the recent past (e.g., the last 7 days).

\section{Remotely Monitoring for Livestock Disease}

On rangelands and forest lands, managers must spend a large amount of time and effort to observe the health of their livestock (Bailey, 2016). Pastures are often large and extensive, especially in arid and semi-arid rangelands. Livestock can be difficult to find because of shrubs, trees and rugged topography. Rough terrain and woody vegetation also limit the use of vehicles to travel through the pastures to find livestock. Often there are few roads and paths through rangeland and forest land pastures. Even allterrain vehicles may not be able to access many areas of wooded and mountainous pastures. Ranchers often use horses to travel through rangeland pastures to find and observe their livestock. Correspondingly, observing livestock in extensive and/or rugged grazing lands is both time consuming and costly.

Accelerometers and other technologies can be used to remotely monitor livestock behavior and have the potential to detect animal welfare concerns including diseases (Bailey et al., 2018). Use of radio frequency identification (RFID) tags and a GrowSafe feeding system was used to successfully monitor cattle feeding in feedlots (Mendes et al., 2011). Hanson and Mo (2014) describe how accelerometers can be used to monitor cow motion and use these data to evaluate the health and well-being of dairy cattle. Accelerometers may be an effective tool to remotely identify fever, lameness and symptoms associated with feeding diseases such as ketosis and displaced abomasums (Helwatkar et al., 2014). Livestock behavior can also be monitored through GPS tracking with or without accelerometers (Augustine and Derner, 2013). Velocity thresholds based on Augustine and Derner (2013) have been used to classify behavior into resting, grazing and traveling by cattle (Nyamuryekung'e et al., 2020). 
As livestock become ill, diurnal behavior patterns typically change. For example, calves that have been challenged with Mannheimia haemolytica spent less time at the grain bunk and less time at the hay feeder than healthy control calves (Theurer et al., 2013). In the same study, accelerometers successfully identified that bacterially challenged calves spent more time lying than control calves. Hutcheson and Cole (1986) found that healthy calves spent more time feeding than morbid calves during their first week in feedlots in a review of 18 studies. The number feeding bouts of healthy steers was greater than morbid steers during the first month of feeding in a feedlot (Sowell et al., 1999). In addition to changes in activity, livestock may show atypical behaviors and other clinical signs associated with some diseases. Cattle and sheep with experimentally induced rabies had the distinct behavioral signs of infection with increased excitability, aggression, head tremors, and vocalizations (Hudson et al., 1996). Tobin et al. (2020) conducted a proof-of-concept study that showed that accelerometers had the potential to detect diseases such as bovine ephemeral fever in a small pasture setting. Heifer activity dropped during the 24 -h period prior to diagnosis of bovine ephemeral fever. The change in activity prior to diagnosis was different from healthy "control" heifers and different from the ill heifer's previous activity. More research is needed to determine robust algorithms for detecting disease, perhaps specific diseases (García et al., 2020). Also, GPS tracking and other sensors may be useful for detecting disease.

\section{Parturition Detection}

Calving and lambing are critical times on rangeland livestock operations. Dystocia, predation, illness and other factors result in early mortality of young livestock (Berger et al., 1992; Bunter et al., 2014; Hinch and Brien, 2014). Advances in development of real-time sensors and GPS tracking provide the potential to remotely monitor for parturition and dystocia which would allow managers to more quickly respond to associated animal welfare concerns (Bailey et al., 2018). During lambing, ewes travel less and separate themselves from the flock, and GPS tracking can identify these behavioral changes and be useful for detecting parturition (Dobos et al., 2014; Fogarty et al., 2020b). In addition, ewes increase the time spent walking, change postures frequently and are generally more restless prior to lambing, which can be identified using accelerometers and used to detect parturition (Fogarty et al., 2020a).

Accelerometers can also be useful for detecting the time of calving (Saint-Dizier and Chastant-Maillard, 2015; Krieger et al., 2019). Miller et al. (2020) reported that accelerometers placed on the tail heads of cows successfully predicted parturition time of beef and dairy cows. Ongoing research in a New Mexico pen study found that, variability of head movements was more useful for detecting lambing than changes in predicted behavior form machine learning. Preliminary results suggested that monitoring changes in an individual's patterns of movements (accelerometer data) may be more useful than using machine learning to predict behavior and monitoring changes in predictions. Typically, behavioral observations and associated accelerometer data are pooled across multiple animals for machine-learning based predictions. In contrast, monitoring deviations in an individual's movement patterns could be more useful for detecting well-being concerns, such as parturition. Variability among individuals may reduce the accuracy of machine learning predictions (Figure 1), which then limits the value of predicted behaviors for detecting parturition and other important well-being issues. However, much more research is needed to confirm these initial findings.

Fogarty et al. (2021) found that distance that a ewe was from other sheep in the flock was the best metric for remotely detecting lambing. Mean distance from peers (MDP) and this distance relative to the flock's MDP and distance to the closest peers were all important. These metrics require knowledge of the position of all animals in the herd (Figure 2). Surprisingly, the only accelerometer-based metric in the four best indicators of lambing was posture change. The combination of four metrics and machine learning was able to detect up to $91 \%$ of lambing events (Fogarty et al., 2021). Detecting the time of calving and lambing would be beneficial for record keeping and providing performance and genetic selection data. However, the largest benefit would be potential to remotely detect dystocia and early calf and lamb mortality.

When dystocia occurs on rangelands and forested lands, both the mother and offspring often die because managers cannot regularly observe all the livestock. Use of real time GPS tracking, accelerometers and other sensors have the potential to reduce the time required to find and assist livestock if dystocia occurs. With real-time GPS tracking and sensors, data can be up-loaded with internet-based tool into a decision-support software system. If the algorithms detect parturition is imminent the manager would be notified with the animal identification, time and location. If the parturition signal from tracking does not change from calving or lambing to post-natal activity patterns in a few hours, there is a good probability there is a problem, and the manager could be sent another message so that someone could be dispatched to check for dystocia.

\section{Water System Failure}

Water is most critical nutrient and welfare issue for livestock grazing arid and semi-arid rangelands (Bailey, 2016). Cattle can lose about $7 \%$ of their body weight per day if they are deprived of water during the summer and die with 5 days of water deprivation and high temperatures (Siebert and Macfarlane, 1975). Consequently, ranchers usually check livestock water frequently (once every 1-3 days) depending on weather conditions and water storage. Real-time GPS tracking and other sensors have the potential to remotely monitor the availability of water on rangelands. Sensors can be used to monitor water levels in drinkers and storage tanks (e.g., SCADALInk SAT110 livestock monitoring system, Calgary, AB, Canada, https://www.scadalink. com/products/satscada/livestock-water-supply-monitoring/) and the data can be transmitted to ranch headquarters directly or via the internet using mobile phone or satellite technologies (Bailey, 2016; Bailey et al., 2018). Ongoing research in our lab, indicates that on-animal sensors and GPS tracking have the potential to detect water systems failures. Normally cattle do not remain near the water tank after watering and typically move over $100 \mathrm{~m}$ from the water tank and rest. During a simulated water failure cattle remained within $100 \mathrm{~m}$ of the tank and were 


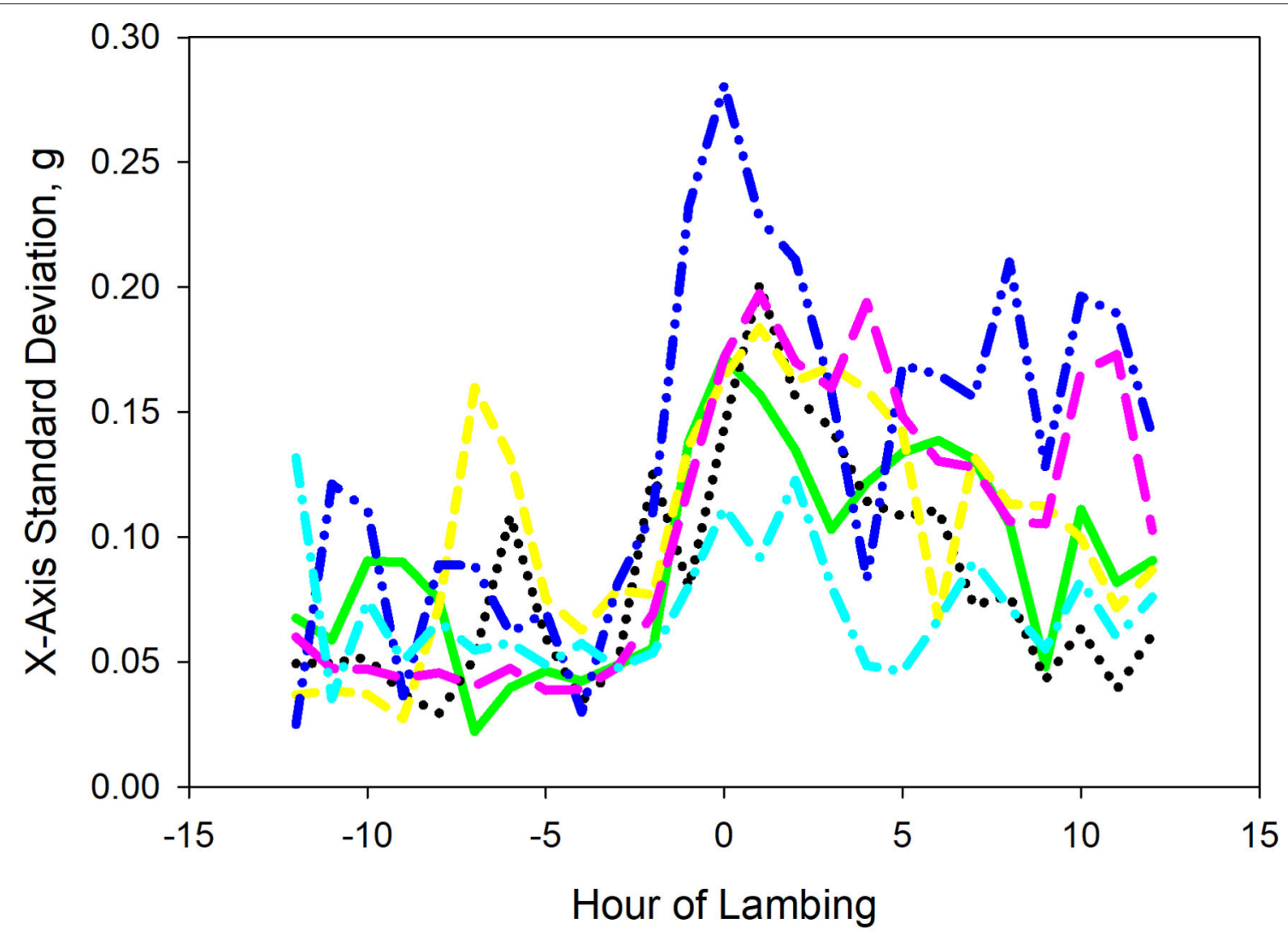

FIGURE 1 | Variability among ewes for an accelerometer-based metric, standard deviation of the $x$-axis (side to side head movements), during the $12 \mathrm{~h}$ before and after lambing. Different line types and colors represent the six ewes in the study. Note: the variation in the $x$-axis were relatively low $3-4 \mathrm{~h}$ prior to lambing (hour 0 ), and the variation rises for the period $2 \mathrm{~h}$ preceding and $2 \mathrm{~h}$ following lambing. However the magnitude of variation differs among ewes.

more active than during normal watering events (Figure 3). Normally, cows moved at least $250 \mathrm{~m}$ from water after drinking.

\section{Social Interactions and Livestock Well-Being}

Cattle, sheep and most other livestock are gregarious animals and social interactions may affect their well-being. Spatial relationships among livestock monitored using GPS tracking and proximity sensors can provide insight into their social relationships (Handcock et al., 2009). Many livestock husbandry practices such as animal purchases and regrouping individuals into different paddocks results in the introduction of unfamiliar animals into a herd. Patison et al. (2010) found that the distance between unfamiliar animals was greater than between familiar animals for several days as the familiarization process progressed. Spatial relationships among cattle is not only an indicator of social interactions but it may be useful for monitoring animal well-being (Patison et al., 2017). Ongoing research in our lab suggests that associations among cattle in rangeland pastures change as forage utilization levels increase. Initially, no differences in association among cows were detected among cows when cattle first started grazing pastures with different stocking densities. Near the end of the grazing (6 weeks) in a smaller pasture (312 ha) with a higher stocking density (0.416 cows/ha), cows were further apart and less associated than in an adjacent but larger pasture (1,096 ha) with a lower stocking density ( 0.123 cows/ha). Cows in the pasture with a higher stocking density may have spread apart in search of forage as the utilization of palatable grasses increased. Social interactions among livestock may be a tool for monitoring animal well-being.

\section{Managing Predator-Livestock Conflict}

Predation can be a critical issue for producers grazing livestock on rangelands and forested lands (Macon, 2020). Predators such as wolves, grizzly bears, mountain lions, wild dogs, and other predators can adversely impact livestock performance as well as injure or kill animals. For examples, cows whose calves have been preyed upon by wolves are more vigilant than cows whose calves were not injured or killed (Kluever et al., 2008). Numerous methods have been used to mitigate the impact of large carnivore predators on livestock including lethal control of predators, herding, fencing, and livestock guardian dogs (Macon et al., 2018; Van Eeden et al., 2018). Livestock guardian dogs (LGD) can be an cost-effective approach to minimize livestock losses to predators if they are effective in reducing losses (Saitone 


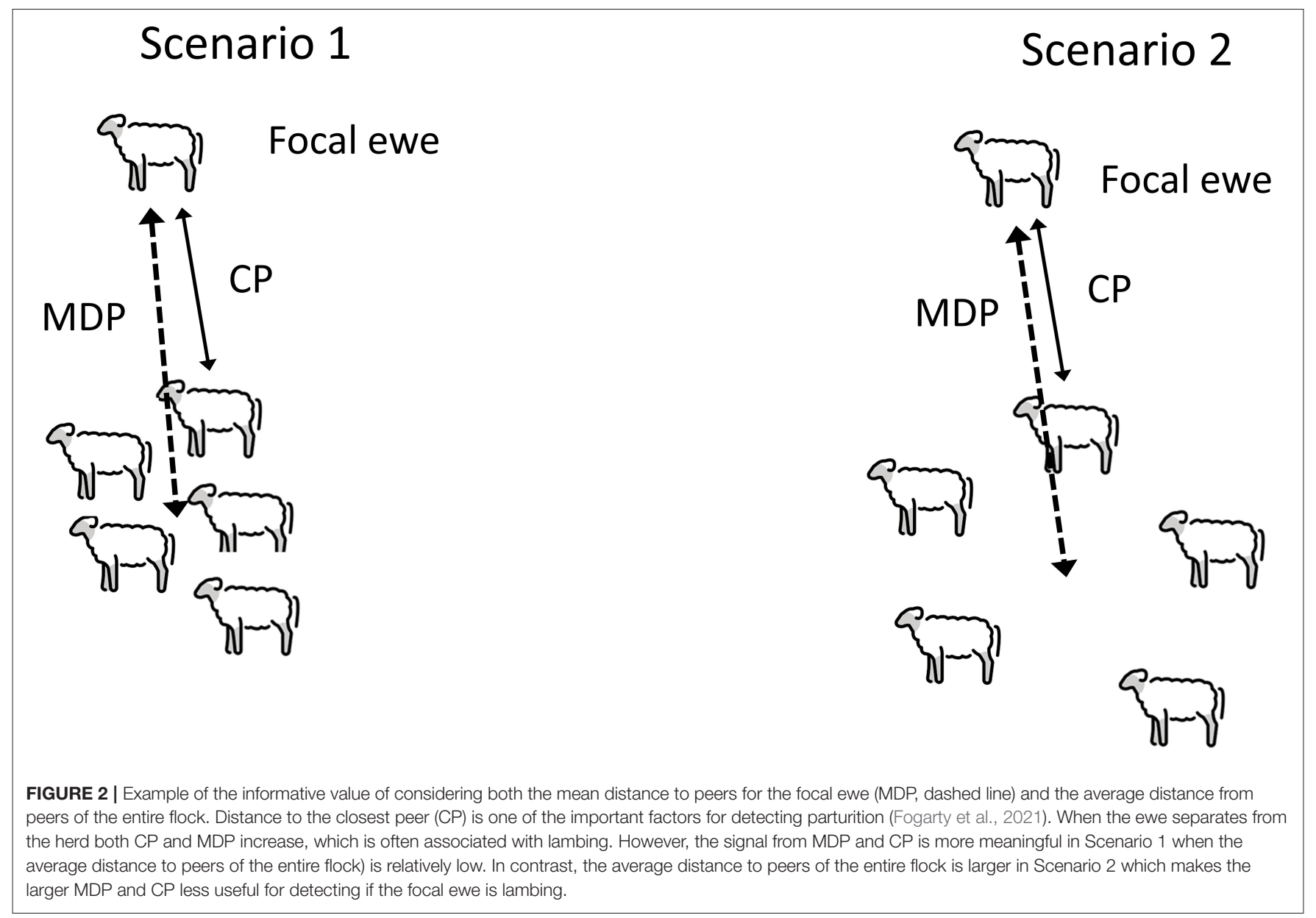

and Bruno, 2020). The risk of predation and the nature of livestock and predator spatial interactions can be evaluated using GPS tracking (Clark et al., 2020). Tracking has been used to study spatial interactions of LGD and sheep (Webber et al., 2015; Mosley et al., 2020). As an example, Allen et al. (2017) found that wild dogs entered LGD territory, which suggested that LGD directly protected sheep rather than excluding wild dogs from their territory in Australia. Young et al. (2019) argues that spatial movements of LGD can be used to monitor their effectiveness. The LGD must remain near the sheep to protect them.

Ongoing developments in real time tracking and sensor monitoring have the potential to detect the presence of predators and efficacy of LGD. Changes in spatial movements (tracking) and movement patterns (accelerometers) could be used to alert managers to the presence of predators and allow them to quickly respond. In addition, real-time tracking would allow herders and managers to make sure LGD remain with their herd so that they can protect the sheep. One of the concerns with LGD is to ensure the bonding process is strong enough for the dogs to remain with the sheep. Additional research is needed to develop algorithms and software to use real time on-animal sensors and tracking to detect predator presence and evaluate the efficacy of LGD and other predator mitigation tools.

\section{REAL-TIME MONITORING AND MANAGEMENT OF GRAZING DISTRIBUTION}

Many of the sustainability issues associated with livestock grazing are the result of uneven grazing distribution (Bailey, 2004). Livestock tend to congregate in areas with greater forage quantity and quality (Senft et al., 1985; Pinchak et al., 1991), areas that are near water (Valentine, 1947) and areas that take less effort to reach, gentle vs. steep slopes (Mueggler, 1965). Cattle use of riparian areas can impact water quality (Agouridis et al., 2005), and cattle grazing on riparian areas can be a critical issue on public lands (Wyman et al., 2006; Roche et al., 2015). Managers have developed a wide range of management practices that can be used to resolve undesirable grazing distribution patterns (Bailey, 2004) and minimize adverse impacts of livestock on riparian areas (George et al., 2011).

\section{Real-Time Riparian Grazing Management}

Livestock grazing management of riparian areas is time sensitive, especially in semi-arid and arid rangelands. Riparian areas typically make up only a small percentage of arid and semiarid rangelands. For example, riparian areas make up 1-2\% 

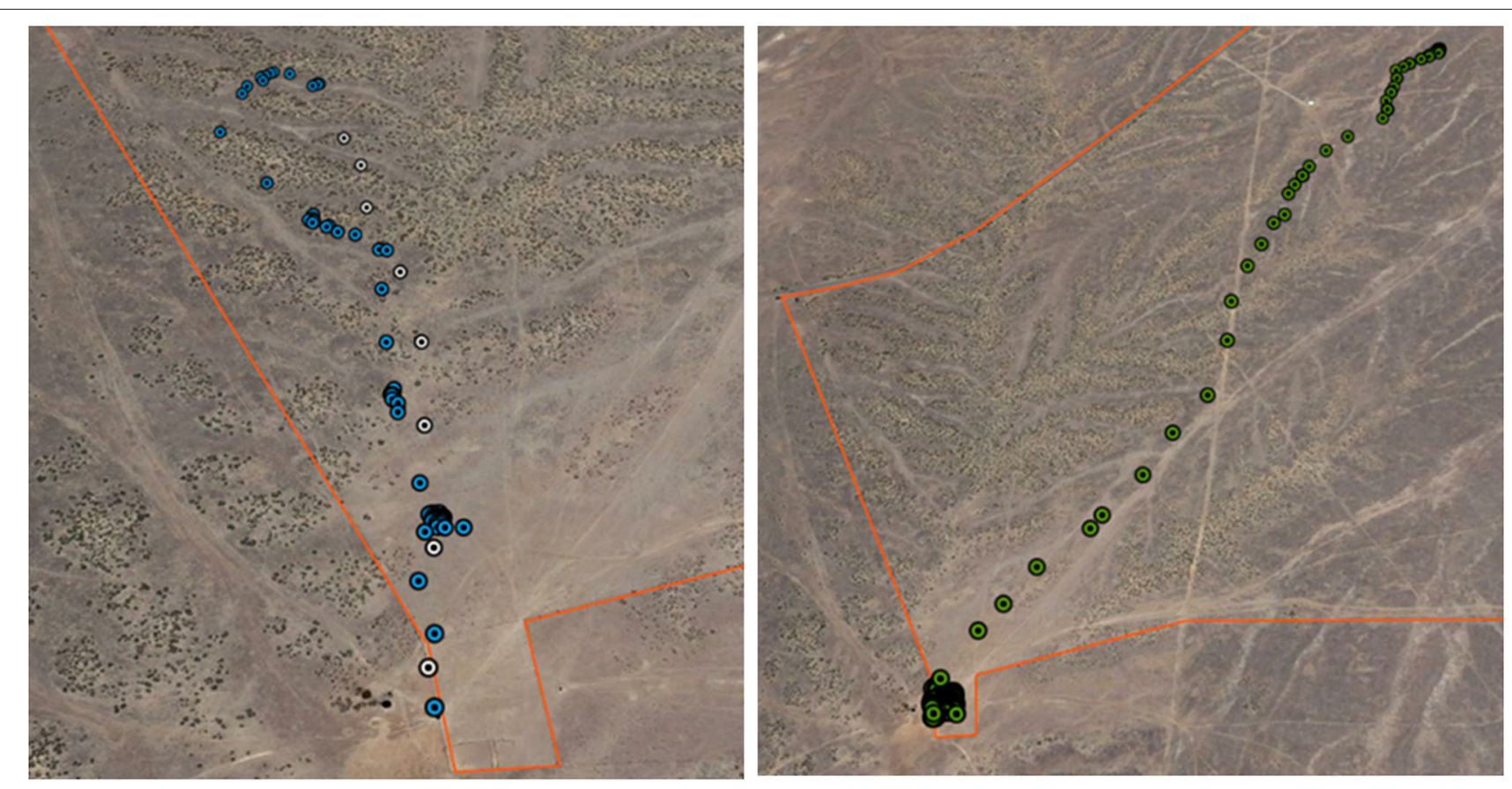

FIGURE 3 | Tracking data of a cow traveling to a water tank, drinking and leaving compared the movement pattern when access to water was denied (simulated water failure). The left map is an example of a normal watering event. White dots on the left graph show a cow walking to water and the blue dots show the cow leaving water. On the right map, the green dots show the cow coming to water and remaining at water during the water system failure simulation. Both maps include tracking that started $30 \mathrm{~min}$. before the cow arrived at the water tank and then an additional hour of tracking.

of rangeland pastures in the Pacific Northwest of the USA (Kauffman and Krueger, 1984). Although they comprise a small areas, riparian areas are essential for maintaining water quality and providing fishery and wildlife habitat (Kauffman and Krueger, 1984) and can potentially produce over $20 \%$ of the forage and over $80 \%$ of the vegetation intake of cattle during the summer (Roath and Krueger, 1982b). On public lands, managers may ask ranchers to end grazing once stubble heights drop to $10-13 \mathrm{~cm}$ (Clary and Leininger, 2000; Tanaka et al., 2007). Cattle are then either moved to a new pasture or moved off the grazing allotment. Low-stress herding and strategic supplement placement can be used to reduce grazing use of riparian areas during the grazing season. Bailey et al. (2008) found that lowstress herding reduced cattle use of riparian areas by $35-50 \%$ compared to controls. If GPS tracking could be transmitted in real time, ranchers could monitor cattle grazing patterns and determine if animals concentrate grazing in riparian areas during the grazing season. Such remotely detected information may allow ranchers to implement low- stress herding and other practices to minimize cattle use of riparian areas before the stubble heights drop below the $10-13 \mathrm{~cm}$ goal and riparian degradation may begin.

\section{Real-Time Upland Grazing Management}

Livestock grazing distribution is a concern for uplands as well as riparian areas. Concentrated grazing can reduce plant vigor and species replacement (Daubenmire, 1940). Eventually, consistent heavy grazing can lead to increased levels of bare ground and active erosion (Blackburn, 1983). Grazing can be heavy in some areas, while other potentially grazeable locations receive little or no use (Norton et al., 2013; Hunt et al., 2014). Grazing distribution practices, such as strategic supplement placement, can improve uniformity of grazing and potentially increase sustainable stocking rates and ranch profitability (Tanaka et al., 2007).

Monitoring livestock grazing distribution on extensive or mountainous rangelands and forested lands is time consuming and expensive with the potential for inaccuracies associated with subjective estimates. Use pattern mapping was designed to measure livestock grazing distribution in an efficient manner (Anderson and Currier, 1973), but this technique relies on subjective observations. Tate et al. (2000) developed a quantitative method of measuring fecal loading on rangelands. Fecal loading can be used to identify areas that cattle use, but it is time consuming to conduct intensive enough measures to assess grazing distribution patterns. In our research, we have measured forage utilization using the height-weight technique at a large number of locations in a pasture to assess grazing distribution (Bailey et al., 2006, 2008). The precision of our lab's approach was dependent on the number of transects measured and the size of the pasture. We used one forage utilization transect for every 3 to 25 ha to assess changes in grazing distribution. Such approaches require time and labor to precisely monitor grazing distribution patterns, and they are not practical for rangeland livestock operations. In addition, vegetation and fecal abundance approaches are typically used at the end of grazing in a pasture 
to measure grazing patterns, because of the time and effort required for data collection. Use pattern mapping (Anderson and Currier, 1973) can be applied periodically during the grazing period, but the precision and accuracy is dependent on the time spent traversing the pasture and observing vegetation conditions. Ranchers, graziers and land managers typically do not measure use patterns of livestock in a pasture during the grazing period because of the required time and labor.

Remote sensing is another tool to monitor forage conditions on rangelands. Numerous studies have shown the satellite and unmanned aerial vehicles (UAV) can provide imagery to estimate spatial and temporal changes in forage production (Reinermann et al., 2020). Indices such as the normalized difference vegetation index (NDVI) can identify spatial variation in vegetation availability associated with different grazing systems (Blanco et al., 2009) and spatial changes in forage abundance that occur at varying distances to water and with uneven livestock grazing distribution (Blanco et al., 2008). Spatial maps of forage productivity derived from satellite and UAV imagers could help managers determine pastures with greater forage abundance throughout the year (Reinermann et al., 2020). Although forage quantity is clearly an important determinant of livestock grazing patterns, forage quality is often more important (Senft et al., 1985; Pinchak et al., 1991). Livestock are attracted to areas of with higher levels of crude protein and digestibility (Bailey, 2005). Satellite and UAV imagery can remotely monitor spatial and temporal changes in forage quality (Thoma et al., 2002; Lugassi et al., 2019; Wijesingha et al., 2020). Mapping spatial and temporal changes in forage quality could be used to determine pastures where there has been recent precipitation and livestock performance should be higher (Trotter, 2010). Such maps would also allow managers to identify areas that have higher forage quality and would be preferred by livestock (e.g., riparian areas) and allow them to focus monitoring efforts to ensure preferred sites are not overgrazed. In addition, remote sensing can be helpful in monitoring the long term benefits for grazing management practices such as water developments and fencing (Rigge et al., 2014).

Global positioning system tracking provides an accurate and quantitative method to assess livestock movement patterns in pastures (Bailey et al., 2018). Recently, the cost of GPS tracking collars have decreased (Knight et al., 2018; Karl and Sprinkle, 2019) so that ranchers may be able to afford to use them to remotely monitor cattle movements. Millward et al. (2020) describe how GPS tracking data could be used to adjust stocking rates based on grazing distribution patterns similar to the approach developed by Holechek (1988) to account for areas that cattle may avoid due to long distances from water and steep slopes. Although GPS tracking clearly shows livestock movements, GPS tracking data does not necessarily reflect patterns in forage utilization (Millward et al., 2020). In Montana studies, GPS tracking data showed similar grazing distribution patterns as height-weight forage utilization transects measured at multiple locations across the study pastures (Bailey et al., 2006, 2008; Bailey and Jensen, 2008). More research is needed to verify that GPS tracking accurately reflects the spatial variation in forage use across pastures.

\section{Genetic Selection for Distribution Using GPS Tracking}

Individual beef cows and likely other livestock express different grazing patterns especially in expansive pastures and rugged terrain. For example, Bailey et al. (2004) reported that cows that used steeper slopes the previous year (hill climbers) spent twice as much time on steep slopes (44-57\% slope) as cows that used gentler terrain the previous year. Hill climber cows were also $46 \mathrm{~m}$ higher in average elevation use than the bottom dweller cows. Several researchers have suggested that selection could be used to take advantage of the variation in spatial grazing patterns of cattle and that ranchers could cull cows that prefer gentler terrain near water and retain cows that use steep terrain and areas far from water (Roath and Krueger, 1982a; Howery et al., 1996; Bailey et al., 1998). Selecting cows that use more rugged terrain (hill climbers) and culling cows that prefer gentle terrain near water (bottom dwellers) has the potential to increase the uniformity of grazing (Bailey et al., 2006). In this Montana study, pastures grazed by hill climbers had more grazing on steep slopes and less use of gentle terrain near water than pastures grazed by bottom dwellers. Stubble heights in riparian areas averaged in pastures grazed by hill climber cows was $13 \mathrm{~cm}$, which is above the recommend riparian stubble height of $10 \mathrm{~cm}$ (Clary and Leininger, 2000), and $8 \mathrm{~cm}$ in pastures grazed by bottom dwellers.

Selection can potentially modify livestock behavioral patterns through both nature and nature (Bailey and Provenza, 2008; Provenza, 2008). Heifers tend to graze the same areas as their mothers graze (Howery et al., 1996). In a cross-fostering study, Howery et al. (1998) demonstrated that the mother's impact on their heifer's grazing patterns could be at least partially attributed learning rather than inheritance alone. Two studies identified that cattle grazing patterns (terrain use traits) were associated with single nucleotide polymorphism (SNP) genetic markers (Bailey et al., 2015; Pierce et al., 2020). The associations between terrain use traits (e.g., slope use and distance traveled from water) and multiple SNP shows that spatial movement patterns are heritable and that these traits are affected by multiple genes; therefore, are polygenic (Pierce et al., 2020). The candidate genes for grazing traits were also associated with other cattle traits such as heat stress, oxygen homeostasis, feed efficiency and growth. Two Montana studies showed that there were no adverse phenotypic correlations between terrain use traits and cow performance traits (Bailey et al., 2001; VanWagoner et al., 2006). Correlations between terrain use traits (slope use and vertical and horizontal distance traveled from water) and cow body condition score, calf weaning weight, calving date and hip height were generally low (between -0.2 and 0.2 ) and inconsistent among years.

More research is needed to develop genetic selection tools for grazing distribution. The biggest limitation has been the cost of measuring grazing distribution. Initially, we used horseback observers to record cattle locations during their morning grazing bouts (Bailey et al., 2006). Several observers were needed to locate up to 180 cows in 100-350 ha pastures during 1.5-2.5 hour period. The labor cost with this approach would be prohibitive for most ranches. The cost for GPS tracking collars was over $\$ 4,000$ when cattle were first being tracked in the late 1990's 
(Anderson et al., 2013). Today, GPS collars can be built and purchased for less than $\$ 250$ (Knight et al., 2018; Karl and Sprinkle, 2019). Even lower cost GPS units are being designed and tested. If real-time GPS tracking tags are used to monitor livestock health and well-being, another benefit would be the ability to document terrain use preferences of individual cows.

Another potential approach to monitor livestock terrain use traits and distribution patterns is through aerial photography using drones or small aircraft (Thomas et al., 2020). A bar code or similar visual identification could be glued or attached to the cattle's backs. High definition cameras could read the animal identification and geoposition cattle location using a GPS on the drone or plane. One limitation of this proposed methodology is that the pastures must relatively open with only a few areas of woody vegetation so that the cattle would readily visible from above. This approach has not been fully developed and tested, but it may be a relatively low cost method for monitoring spatial patterns of grazing cattle in rangelands dominated by grasses and forbs.

The identification of genetic markers for grazing distribution traits reduces the need to track cows for quantifying the terrain use phenotype. To make progress using genetic selection, it is most critical to select sires that have superior genotypes for the desired trait. The most progress can be made through bull selection, as opposed to culling inferior cows or selecting superior replacement females (Bourdon, 2000). The selection differential for bulls is much greater than for replacement heifers or culling inferior cows. Unfortunately, it is difficult to accurately assess the terrain use phenotype of bulls. During the breeding season, bull libido likely affects their spatial movements more than tendencies to travel for forage. Outside of the breeding season, bulls are typically kept together in the same pasture. The number of bulls is often $<40$ in all but large operations. Stephenson et al. (2016) reported that groups of 40 or less cattle tended to stay together, which limits animal's willingness to express differences in individual movement patterns. With the identification of genetic markers and candidate genes for terrain use, genomic breeding values can be developed. Genomic breeding values are a useful selection approach for hard to measure traits such as terrain use (Eggen, 2012). Genomic breeding values use single nucleotide polymorphisms or other genetic markers to estimate an individual's breeding value for the trait. Deoxyribonucleic acid (DNA) samples could be obtained from bulls and replacement females and processed for the appropriate genetic markers (i.e., genotypes). Bulls and replacement heifers could then be ranked for their potential to improve terrain use using their genomic breeding values. However, it must be acknowledged that genetic evaluation, with or without assistance of genomics, to estimate breeding values and their accuracies requires large scale data collection with ample number of contemporary group comparisons of familiallyrelated animals; therefore, improvement in data acquisition technologies for tracking large numbers of cows is needed to help develop strong genetic improvement programs.

Another factor that is hindering development of breeding values for terrain use of beef cattle is that topography, water locations, vegetation types and forage quantity and quality vary tremendously among pastures, both spatially (terrain and water location) and temporally (forage quantity and quality). The impact of slope and horizontal and vertical distance to water on cattle grazing patterns is complex and nonlinear (Bailey, 2005). For example, steep slopes have less impact if they are located close to water compared to the effect of steep slopes at locations far from water (Mueggler, 1965). The variation in terrain among pastures and locations makes it difficult to quantify the effort cattle incur climbing steep slopes, traveling long distance to water and reaching high elevations. Pierce et al. (2020) concluded that this variability associated with topographic complexity contributed to the low proportion of genetic variation in grazing distribution explained by quantitative trait loci (SNP genetic markers). Tools such as resource selection functions (Nielson and Sawyer, 2013) and topographic indices (Gersie et al., 2019) may be useful for comparing grazing patterns across pastures and adjusting to the variability associated with terrain and water locations. Bailey et al. (2015) developed indices using ratios in an attempt to integrate the impacts of slope, elevation and horizontal distance to water. These indices normalized the values of topographic metrics (slope, distance to water and elevation) by dividing by the mean and multiplying by 100 and then averaged the metrics which weighted them equally. However, ongoing research shows that the impacts of slope and vertical and horizontal distance from water varies on cattle distribution is different for each pasture. The coefficients of resource selection functions may be a good tool for weighting the impact of topographic variables on cattle distribution if the topographic metrics are scaled (e.g., feature scaling). Rather than using equal weight for slope, elevation and distance to water the coefficients could be applied to scaled terrain metrics to produce an index that should be more comparable from one pasture to another. Gersie et al. (2019) found that topographic position classes (TPC) could be used to predict cattle distribution on multiple short grass prairie pastures. Use of TPC or similar terrain classifications may be another alternative to quantify the effort to use rugged and extensive rangeland pastures by individual cows across multiple locations.

\section{Virtual Fencing}

Virtual fencing is a tool to enclose and control livestock without ground-based traditional fencing (Anderson, 2007). Recent systems use GPS receivers to track the animal, GIS algorithms to establish boundaries, radio frequencies to communicated with managers, sound cues to alert animals of approaching boundaries and mild electric shock to discourage animals from crossing boundaries (Campbell et al., 2017). Virtual boundaries can be placed in any location and easily moved to exclude animals from environmentally sensitive areas, modify stocking density, implement rotational grazing systems and modify grazing distribution patterns (Anderson et al., 2014). Campbell et al. (2019a) demonstrated that virtually fencing could be used to exclude cattle from riparian areas. Cattle quickly learn to avoid excluded areas and this learning can be facilitated through social interactions (Keshavarzi et al., 2020). However, Markus (2002) found that cattle with inactive devices readily crossed virtual boundaries and cattle while active devices did 
not enter excluded areas during simulated equipment failures. Virtual fencing systems have promise to control livestock movements, but the cost of the devices compared to traditional fencing may limit adoption by rangeland livestock producers (Banhazi et al., 2012; Umstatter et al., 2015). In addition, the public may have concerns with virtual fencing (Stampa et al., 2020). For example, Markus et al. (2014) found that cattle avoided an excluded area days after the virtual fencing system was discontinued, while cattle readily entered the excluded area when electric fencing was dismantled. In contrast, Campbell et al. (2019b) found that fecal cortisone levels were similar for cattle constrained virtual fencing and traditional electric fencing. Virtual fencing may become a prominent tool in precision livestock management if educational programs are developed to address public concerns with the welfare of livestock constrained by virtual fencing (Stampa et al., 2020), and the cost of virtual fencing equipment drops to a level comparable to labor, material and maintenance costs of traditional fencing.

\section{DATA PROCESSING AND TRANSFER}

Currently, most low-cost GPS collars store the tracking data on the collar (store on board, SOB), and the cattle must be gathered and placed in corrals so that the collars can be retrieved. The SOB tracking equipment does not allow managers to remotely monitor livestock distribution or animal behavior in real-time or near real time. This is a major limitation because managers can use GPS tracking to remotely monitor livestock health and well-being or spatial distribution pasterns when grazing is occurring in a pasture and respond when concerns or opportunities arise. Precision livestock management monitoring with SOB technology is only useful for proof of concept, algorithm development and simulated well-being issues. Realtime tracking is critical to assess changes in animal movements, spatial distribution and behavior that could detect animal health and welfare concerns. In addition, development of real time or near real time GPS tracking may allow managers to identify issues with livestock spatial distribution, implement management practices while the pasture is grazed and monitor the success of the management interventions (Bailey et al., 2018). Smartbow (Zoetis, Weibern, Austria) has a real-time tracking system for dairy cows (Wolfger et al., 2017). Moovement (Brisbane, QLD, Australia, https://www.moovement.com.au) have developed a commercially available GPS ear tag that records animal position every hour and transmits this data to a LoRa (Long Range) antenna (Sanchez-Iborra et al., 2018) and then it is forwarded to the internet using cellular phone technology. The ear tags are designed to transmit data from the ear tag $8 \mathrm{~km}$ (line of sight) to the LoRa antenna. The Moovement system also contains an iPhone application (app) that allows ranchers and graziers the opportunity to see the most recent location of tracked cattle. This Moovement app uses Google Earth imagery for visualizing cattle locations. Other companies are developing real-time and near real-time GPS tracking systems for livestock grazing rangeland, but their products are not currently commercially available (Table 1).

Currently, most commercially accelerometers produce massive amounts of data, because they record movement (acceleration) of three axes at $12-25 \mathrm{~Hz}$. Transferring such large amounts of data in real time or near real time is prohibitive for livestock grazing rangeland because of the battery demand for transmission. To reduce the size of the transmission from the sensor (e.g., accelerometer), data must be processed and summarized. The process of analyzing and processing sensor data on the device is termed "edge computing" or "front end processing” (Habib ur Rehman et al., 2016, 2017). Cheng et al. (2014) used a locally sensitive Bloom filter to reduce the size of sensor data. Edge computing can use historic data and machine learning processes (García et al., 2020) such as random forests and signal vector machine to detect important states or events from data streams obtained from sensors (Park et al., 2018). Hu et al. (2016) demonstrated that edge computing reduced response time and energy use of mobile devices. For livestock, sensors must be small and large batteries are not practical, especially for ear tag sensors. Ear tag sensors are preferred by ranchers and graziers and are a reliable location for monitoring activity using accelerometers (Barwick et al., 2018). Herddogg (https:// www.herddogg.com/) is developing a commercially available ear tag with an accelerometer to monitor livestock health and well-being. Data from the ear tag are transferred from the tag to a reader using blue tooth technology when the animal approaches the reader which is placed in a frequently visited location (e.g., water). Herddogg tri-axial accelerometer readings recorded at $24 \mathrm{~Hz}$ are compressed to a single value every $6 \mathrm{~min}$. This reduces the size of transferred data and minimizes battery consumption.

Algorithms that are used to detect illness, well-being issues, spatial distribution concerns and other problems from realtime streams of location, accelerometer and other sensors must be developed and evaluated using experimental and on-ranch studies. Scientists addressing precision livestock management will be critical part of this research. We advocate for increased levels of research in this area of study and encourage interdisciplinary approaches with animal and range scientists working with computer scientists and electrical engineers.

Ideally, precision livestock management systems will include all the mature livestock on a ranch and perhaps even offspring. Monitoring and tracking all livestock maximizes opportunities to identify issues and concerns with individual animals and those for the herd. However, this may not be economically feasible because of equipment cost and subscriptions for transmitting data to the internet. For example, some systems rely on subscriptions for satellite data transfer. A less costly alternative (sentinel animals) relies on a limited number of remotely monitored livestock (Neo and Tan, 2017). Sentinel animals and sentinel herds are commonly used to monitor the occurrence of diseases such as blue tongue virus (Giovannini et al., 2004). For precision livestock management, tracking and monitoring sentinel animals would be helpful for monitoring the overall health of the herd, but not individual animals. Correspondingly, it would not be useful for detecting parturition or to identify animals that require treatment for an illness. However, sentinel 
TABLE 1 | Non-exhaustive listing of companies that have developed or are developing on-animal, real-time or near-real time tracking and sensors for livestock grazing rangelands.

\begin{tabular}{|c|c|c|c|c|c|c|c|}
\hline Company & Country & Device & Type & $\begin{array}{l}\text { Real or near } \\
\text { time }\end{array}$ & $\begin{array}{l}\text { Data } \\
\text { transmission }\end{array}$ & Status & Website \\
\hline Moovement & Australia & GPS tracking & Tag & Real & $\begin{array}{l}\text { LoRa and cell } \\
\text { phone }\end{array}$ & Available & $\begin{array}{l}\text { https://www.moovement. } \\
\text { com.au/ }\end{array}$ \\
\hline Moonitor & Israel & GPS tracking/accelerometer & Collar & Real & Satellite & Available & $\begin{array}{l}\text { https://www.moonitorcows. } \\
\text { com/ }\end{array}$ \\
\hline $\begin{array}{l}\text { Smart } \\
\text { Paddock }\end{array}$ & Australia & GPS tracking & Collar or tag & Real & LoRa & Available & http://smartpaddock.com/ \\
\hline $\begin{array}{l}\text { Digital Matters } \\
\text { Oyster } 2\end{array}$ & USA & GPS tracking & $\begin{array}{l}\text { Attach device } \\
\text { to collar }\end{array}$ & Real & Cell phone & Available & $\begin{array}{l}\text { https://www.digitalmatter. } \\
\text { com/devices/oyster2/ }\end{array}$ \\
\hline $\begin{array}{l}\text { Smarter } \\
\text { Technologies }\end{array}$ & UK & GPS tracking & Collar & Real & Orion Network & Available & $\begin{array}{l}\text { https://smartertechnologies. } \\
\text { com/smarter-products/gps- } \\
\text { cattle-collar/ }\end{array}$ \\
\hline Cattle Watch & South Africa & GPS tracking/ccelerometer & Collar and tag & Real & $\begin{array}{l}\text { Satellite or cell } \\
\text { phone }\end{array}$ & Available & $\begin{array}{l}\text { http://www.cattlewatch.co. } \\
\text { za/ }\end{array}$ \\
\hline CeresTag & Australia & GPS tracking & Tag & Real & Satellite & Development & https://www.cerestag.com/ \\
\hline AeXonis & USA & GPS tracking & Tag & & & Development & \\
\hline Herddogg & USA & Accelerometer/thermometer & Tag & Near real & Blue tooth & Development & $\begin{array}{l}\text { https://www.herddogg. } \\
\text { com/ }\end{array}$ \\
\hline Alflex/SCR & Israel & Accelerometer & $\begin{array}{l}\text { Collar and ear } \\
\text { tag }\end{array}$ & Real & Proprietary & Available & $\begin{array}{l}\text { https://www.allflex.global/ } \\
\text { au/product/sensehub-for- } \\
\text { beef/ }\end{array}$ \\
\hline Quantified AG & USA & Accelerometer/thermometer & Tag & & LoRa & Development & https://quantifiedag.com/ \\
\hline
\end{tabular}

animal tracking could potentially be used to help detect water system failure and spatial distribution issues. If sentinel animals spent more time at a water tank, it would be likely that there is a problem with the water system. Similarly, if sentinel animals concentrate in an environmentally sensitive area of a pasture, this would be an indication of potential over grazing and resource degradation.

\section{CONCLUSIONS}

Development of real-time and near-time tracking has facilitated the development of precision livestock management, which can allow managers to remotely monitor livestock health and wellbeing. Real-time tracking could also monitor spatial movement patterns of livestock and potentially identify areas where animals are concentrated and may be overgrazing and causing resource degradation. Algorithms in precision livestock management system would detect animal well-being issues and resource concerns, and the manager would be notified and could respond as soon as possible. Ongoing research is providing proof of concepts of the value of real-time tracking and monitoring. Accelerometers can remotely monitor the decrease in activity associated with the onset of illness. Real-time GPS tracking is an on-animal sensor method for detecting water system failures. The combination of GPS tracking of all ewes and accelerometer monitoring provides an accurate method for detecting the onset of lambing. The identification of genetic markers that are associated with terrain use demonstrate that grazing distribution traits are inherited. New uses for GPS tracking and evaluations of novel processing approaches using geographical information systems and resource selection functions may facilitate development of genetic selection tools for terrain use of beef cattle. To develop these genetic tools, collection of data from large numbers of cattle is also needed. Precision livestock management is an exciting new field of study that has potential to reduce labor costs, enhance livestock well-being and improve the economic and environmental sustainability of rangeland livestock operations.

\section{AUTHOR CONTRIBUTIONS}

DB prepared the initial draft. All authors contributed to the research and analyses used in the development of this paper. All authors edited and improved the paper.

\section{FUNDING}

Research and concepts described in this paper by the authors were supported by funding from several sources: the Harold James Family Trust and studies at Deep Well Ranch, Prescott Arizona; the Australian-American Fulbright Commission; and the National Institute of Food and Agriculture, U.S. Department of Agriculture, under award number SW15-015 through the Western Sustainable Agriculture Research and Education program under subaward number [140867024-256]. USDA is an equal opportunity employer and service provider. 


\section{REFERENCES}

Agouridis, C. T., Workman, S. R., Warner, R. C., and Jennings, G. D. (2005). Livestock grazing management impacts on stream water quality: a review. J. Am. Water Resour. Assoc. 41, 591-606. doi: 10.1111/j.1752-1688.2005.tb03757.x

Allen, L. R., Stewart-Moore, N., Byrne, D., and Allen, B. L. (2017). Guardian dogs protect sheep by guarding sheep, not by establishing territories and excluding predators. Anim. Prod. Sci. 57, 1118-1127. doi: 10.1071/AN16030

Anderson, D. M. (2007). Virtual fencing-past, present and future. Rangeland J. 29, 65-78. doi: 10.1071/RJ06036

Anderson, D. M., Estell, R. E., and Cibils, A. F. (2013). Spatiotemporal cattle data-a plea for protocol standardization. Positioning 4, 115-136. doi: 10.4236/pos.2013.41012

Anderson, D. M., Estell, R. E., Holechek, J. L., Ivey, S., and Smith, G. B. (2014). Virtual herding for flexible livestock management-a review. Rangeland J. 36, 205-221. doi: 10.1071/RJ13092

Anderson, E. W., and Currier, W. F. (1973). Evaluating zones of utilization. J. Range Manag. 26, 87-91. doi: 10.2307/3896457

Augustine, D. J., and Derner, J. D. (2013). Assessing herbivore foraging behavior with GPS collars in a semiarid grassland. Sensors (Basel) 13, 3711-3723. doi: 10.3390/s130303711

Bailey, D., Trotter, M., Knight, C., and Thomas, M. (2017). "Advancements in rangeland livestock management: new technologies meet the old frontier of extensive grazing systems," in 1st Asian-Australasian Conference on Precision Agriculture and Livestock Farming, ed. W. Nelson (Hamilton: Zendo), 1-6.

Bailey, D. W. (2004). Management strategies for optimal grazing distribution and use of arid rangelands. J. Anim. Sci. 82, E147-E153.

Bailey, D. W. (2005). Identification and creation of optimum habitat conditions for livestock. Rangeland Ecol. Manage. 58, 109-118. doi: 10.2111/03-147.1

Bailey, D. W. (2016). "Grazing and animal distribution," in Animal Welfare in Extensive Systems, eds J. J. Villalba and X. Manteca (Sheffield: $5 \mathrm{M}$ Publishing), 53-77.

Bailey, D. W., Dumont, B., and Wallisdevries, M. F. (1998). Utilization of heterogeneous grasslands by domestic herbivores: theory to management. Ann. Zootech. 47, 321-333. doi: 10.1051/animres:19980501

Bailey, D. W., and Jensen, D. (2008). Method of supplementation may affect cattle grazing patterns. Rangeland Ecol. Manage. 61, 131-135. doi: 10.2111/06-167.1

Bailey, D. W., Keil, M. R., and Rittenhouse, L. R. (2004). Research observation: daily movement patterns of hill climbing and bottom dwelling cows. J. Range Manage. 57, 20-28. doi: 10.2307/4003950

Bailey, D. W., Kress, D. D., Anderson, D. C., Boss, D. L., and Miller, E. T. (2001). Relationship between terrain use and performance of beef cows grazing foothill rangeland. J. Anim. Sci. 79, 1883-1891. doi: 10.2527/2001.7971883x

Bailey, D. W., Lunt, S., Lipka, A., Thomas, M. G., Medrano, J. F., Cánovas, A., et al. (2015). Genetic influences on cattle grazing distribution: association of genetic markers with terrain use in cattle. Rangeland Ecol. Manage. 68, 142-149. doi: 10.1016/j.rama.2015.02.001

Bailey, D. W., and Provenza, F. D. (2008). "Mechanisms determining largeherbivore distribution," in Resource ecology: Spatial and Temporal Dynamics of Foraging, eds H. H. T. Prins and F. Van Langevelde (Dordrecht: Springer), 7-28. doi: 10.1007/978-1-4020-6850-8_2

Bailey, D. W., Trotter, M. G., Knight, C. W., and Thomas, M. G. (2018). Use of GPS tracking collars and accelerometers for rangeland livestock production research. Transl. Anim. Sci. 2, 81-88. doi: 10.1093/tas/txx006

Bailey, D. W., VanWagoner, H. C., and Weinmeister, R. (2006). Individual animal selection has the potential to improve uniformity of grazing on foothill rangeland. Rangeland Ecol. Manage. 59, 351-358. doi: 10.2111/04-165R2.1

Bailey, D. W., VanWagoner, H. C., Weinmeister, R., and Jensen, D. (2008). Evaluation of low-stress herding and supplement placement for managing cattle grazing in riparian and upland areas. Rangeland Ecol. Manage. 61, 26-37. doi: $10.2111 / 06-130.1$

Banhazi, T. M., Lehr, H., Black, J., Crabtree, H., Schofield, P., Tscharke, M., et al. (2012). Precision livestock farming: an international review of scientific and commercial aspects. Int. J. Agric. Biol. Eng. 5, 1-9. doi: 10.3965/j.ijabe.20120503.001

Barwick, J., Lamb, D. W., Dobos, R., Welch, M., and Trotter, M. (2018). Categorising sheep activity using a tri-axial accelerometer. Comput. Electron. Agric. 145, 289-297. doi: 10.1016/j.compag.2018.01.007
Berckmans, D. (2014). Precision livestock farming technologies for welfare management in intensive livestock systems. Sci. Techn. Rev. Off. Int. Epizoot. 33, 189-196. doi: 10.20506/rst.33.1.2273

Berger, P. J., Cubas, A. C., Koehler, K. J., and Healey, M. H. (1992). Factors affecting dystocia and early calf mortality in Angus cows and heifers1. J. Anim. Sci. 70, 1775-1786. doi: 10.2527/1992.7061775x

Blackburn, W. (1983). Livestock grazing impacts on watersheds. Rangelands $5,123-125$.

Blanco, L., Aguilera, M., Paruelo, J., and Biurrun, F. (2008). Grazing effect on NDVI across an aridity gradient in Argentina. J. Arid Environ. 72, 764-776. doi: 10.1016/j.jaridenv.2007.10.003

Blanco, L. J., Ferrando, C. A., and Biurrun, F. N. (2009). Remote sensing of spatial and temporal vegetation patterns in two grazing systems. Rangeland Ecol. Manage. 62, 445-451. doi: 10.2111/08-213.1

Bourdon, R. M. (2000). Understanding Animal Breeding. Upper Saddle River, NJ: Prentice Hall.

Bunter, K. L., Johnston, D. J., Wolcott, M. L., and Fordyce, G. (2014). Factors associated with calf mortality in tropically adapted beef breeds managed in extensive Australian production systems. Anim. Prod. Sci. 54, 25-36. doi: 10.1071/AN12421

Campbell, D., Lea, J., Farrer, W., Haynes, S., and Lee, C. (2017). Tech-Savvy Beef Cattle? How heifers respond to moving virtual fence lines. Animals 7:72. doi: $10.3390 /$ ani7090072

Campbell, D. L., Haynes, S. J., Lea, J. M., Farrer, W. J., and Lee, C. (2019a). Temporary exclusion of cattle from a riparian zone using virtual fencing technology. Animals 9:5. doi: 10.3390/ani9010005

Campbell, D. L., Lea, J. M., Keshavarzi, H., and Lee, C. (2019b). Virtual fencing is comparable to electric tape fencing for cattle behavior and welfare. Front. Vet. Sci. 6:445. doi: 10.3389/fvets.2019.00445

Cheng, Y., Jiang, P., and Peng, Y. (2014). "Increasing big data front end processing efficiency via locality sensitive bloom filter for elderly healthcare," in 2014 IEEE Symposium on Computational Intelligence in Big Data (CIBD), 1-8. doi: 10.1109/CIBD.2014.7011524

Clark, P. E., Chigbrow, J., Johnson, D. E., Larson, L. L., Nielson, R. M., Louhaichi, M., et al. (2020). Predicting spatial risk of wolf-cattle encounters and depredation. Rangeland Ecol. Manage. 73, 30-52. doi: 10.1016/j.rama.2019.08.012

Clary, W. P., and Leininger, W. C. (2000). Stubble height as a tool for management of riparian areas. J. Range Manage. 53, 562-573. doi: 10.2307/4003148

Daubenmire, R. F. (1940). Plant succession due to overgrazing in the Agropyron bunchgrass prairie of southeastern Washington. Ecology 21, 55-64. doi: $10.2307 / 1930618$

Dobos, R. C., Dickson, S., Bailey, D. W., and Trotter, M. G. (2014). The use of GNSS technology to identify lambing behaviour in pregnant grazing Merino ewes. Anim. Prod. Sci. 54, 1722-1727. doi: 10.1071/AN14297

Eggen, A. (2012). The development and application of genomic selection as a new breeding paradigm. Anim. Front. 2, 10-15. doi: 10.2527/af.2011-0027

Fogarty, E., Swain, D., Cronin, G., Moraes, L., and Trotter, M. (2020a). Can accelerometer ear tags identify behavioural changes in sheep associated with parturition? Anim. Reprod. Sci. 216:106345. doi: 10.1016/j.anireprosci.2020.106345

Fogarty, E. S., Swain, D. L., Cronin, G. M., Moraes, L. E., Bailey, D. W., and Trotter, M. (2021). Developing a simulated online model that integrates GNSS, accelerometer and weather data to detect parturition events in grazing sheep: a machine learning approach. Animals 11:303. doi: 10.3390/ani11020303

Fogarty, E. S., Swain, D. L., Cronin, G. M., Moraes, L. E., Bailey, D. W., and Trotter, M. G. (2020b). Potential for autonomous detection of lambing using global navigation satellite system technology. Anim. Prod. Sci. 60, 1217-1226. doi: 10.1071/AN18654

García, R., Aguilar, J., Toro, M., Pinto, A., and Rodríguez, P. (2020). A systematic literature review on the use of machine learning in precision livestock farming. Comput. Electron. Agric. 179:105826. doi: 10.1016/j.compag.2020.105826

Gary, L. A., Sherritt, G. W., and Hale, E. B. (1970). Behavior of Charolais Cattle on Pasture. J. Anim. Sci. 30, 203-206. doi: 10.2527/jas1970.302203x

George, M. R., Jackson, R. D., Boyd, C. S., Tate, K. W., and Briske, D. (2011). "A scientific assessment of the effectiveness of riparian management practices," in Conservation Benefits of Rangeland Practices: Assessment, Recommendations, and Knowledge Gaps (Lawrence, KS: Allen Press,), 429. 
Gersie, S. P., Augustine, D. J., and Derner, J. D. (2019). Cattle grazing distribution in shortgrass steppe: influences of topography and saline soils. Rangeland Ecol. Manage. 72, 602-614. doi: 10.1016/j.rama.2019.01.009

Giovannini, A., Calistri, P., Conte, A., Savini, L., Nannini, Patta, C., D., et al. (2004). Bluetongue virus surveillance in a newly infected area. Vet. Ital. 40, 188-197.

Gregorini, P. (2012). Diurnal grazing pattern: its physiological basis and strategic management. Anim. Prod. Sci. 52, 416-430. doi: 10.1071/AN11250

Habib ur Rehman, M., Jayaraman, P. P., Malik, S. U. R., Khan, A. U. R., and Medhat Gaber, M. (2017). Rededge: a novel architecture for big data processing in mobile edge computing environments. J. Sensor Actuator Netw. 6:17. doi: 10.3390/jsan6030017

Habib ur Rehman, M., Liew, C. S., Abbas, A., Jayaraman, P. P., Wah, T. Y., and Khan, S. U. (2016). Big data reduction methods: a survey. Data Sci. Eng. 1, 265-284. doi: 10.1007/s41019-016-0022-0

Handcock, R. N., Swain, D. L., Bishop-Hurley, G. J., Patison, K. P., Wark, T., Valencia, P., et al. (2009). Monitoring animal behaviour and environmental interactions using wireless sensor networks, GPS collars and satellite remote sensing. Sensors 9, 3586-3603. doi: 10.3390/s90503586

Hanson, D., and Mo, C. (2014). Monitoring cattle motion using 3-axis acceleration and GPS data. J. Res. Agric. Anim. Sci. 2, 1-8.

Helwatkar, A., Riordan, D., and Walsh, J. (2014). "Sensor technology for animal health monitoring," in 8th International Conference on Sensing Technology (Liverpool), 266-271.

Herbel, C. H., and Nelson, F. N. (1966). Activities of Hereford and Santa Gertrudis cattle on southern New Mexico range. J. Range Manage. 19, 173-176. doi: $10.2307 / 3895642$

Hinch, G., and Brien, F. (2014). Lamb survival in Australian flocks: a review. Anim. Prod. Sci. 54, 656-666. doi: 10.1071/AN13236

Holechek, J. L. (1988). An approach for setting the stocking rate. Rangelands $10,10-14$.

Howery, L. D., Provenza, F. D., Banner, R. E., and Scott, C. B. (1996). Differences in home range and habitat use among individuals in a cattle herd. Appl. Anim. Behav. Sci. 49, 305-320. doi: 10.1016/0168-1591(96)01059-3

Howery, L. D., Provenza, F. D., Banner, R. E., and Scott, C. B. (1998). Social and environmental factors influence cattle distribution on rangeland. Appl. Anim. Behav. Sci. 55, 231-244. doi: 10.1016/S0168-1591(97)00054-3

Hu, W., Gao, Y., Ha, K., Wang, J., Amos, B., Chen, Z., et al. (2016). "Quantifying the impact of edge computing on mobile applications," in Proceedings of the 7th ACM SIGOPS Asia-Pacific Workshop on Systems (New York; NY), 1-8.

Hudson, L., Weinstock, D., Jordan, T., and Bold-Fletcher, N. (1996). Clinical features of experimentally induced rabies in cattle and sheep. J. Vet. Med. Ser. B 43, 85-95. doi: 10.1111/j.1439-0450.1996.tb00292.x

Hunt, L. P., McIvor, J. G., Grice, A. C., and Bray, S. G. (2014). Principles and guidelines for managing cattle grazing in the grazing lands of northern Australia: stocking rates, pasture resting, prescribed fire, paddock size and water points-a review. Rangeland J. 36, 105-119. doi: 10.1071/RJ13070

Hutcheson, D. P., and Cole, N. A. (1986). Management of transit-stress syndrome in cattle: nutritional and environmental effects. J. Anim. Sci. 62, 555-560. doi: $10.2527 /$ jas $1986.622555 \mathrm{x}$

Karl, J. W., and Sprinkle, J. E. (2019). Low-cost livestock global positioning system collar from commercial off-the-shelf parts. Rangeland Ecol. Manage. 72, 954-958. doi: 10.1016/j.rama.2019.08.003

Kauffman, J. B., and Krueger, W. C. (1984). Livestock impacts on riparian ecosystems and streamside management implications. A review. J. Range Manage. 37, 430-438. doi: 10.2307/3899631

Keshavarzi, H., Lee, C., Lea, J., and Campbell, D. (2020). Virtual fence responses are socially facilitated in beef cattle. Front. Vet. Sci. 30;7:543158. doi: $10.3389 /$ fvets.2020.543158

Kilgour, R. J., Uetake, K., Ishiwata, T., and Melville, G. J. (2012). The behaviour of beef cattle at pasture. Appl.Anim. Behav. Sci. 138, 12-17. doi: 10.1016/j.applanim.2011.12.001

Kluever, B. M., Breck, S. W., Howery, L. D., Krausman, P. R., and Bergman, D. L. (2008). Vigilance in cattle: the influence of predation, social interactions, and environmental factors. Rangeland Ecol. Manage. 61, 321-328. doi: 10.2111/07-087.1

Knight, C. W., Bailey, D. W., and Faulkner, D. (2018). Low-cost global positioning system tracking collar for use on cattle. Rangeland Ecol. Manag. 71, 506-508. doi: 10.1016/j.rama.2018.04.003
Krieger, S., Oczak, M., Lidauer, L., Berger, A., Kickinger, F., Öhlschuster, M., et al. (2019). An ear-attached accelerometer as an on-farm device to predict the onset of calving in dairy cows. Biosyst. Eng. 184, 190-199. doi: 10.1016/j.biosystemseng.2019.06.011

Leonard, S., Kinch, G., Elsbernd, V., Borman, M., and Swanson, S. (1997). Riparian Area Management: Grazing Management for Riparian Wetland Areas. Denver, CO: USDI Bureau of Land Management, National Applied Resource Sciences Center.

Lugassi, R., Zaady, E., Goldshleger, N., Shoshany, M., and Chudnovsky, A. (2019). Spatial and temporal monitoring of pasture ecological quality: sentinel-2-based estimation of crude protein and neutral detergent fiber contents. Remote Sen. 11:799. doi: 10.3390/rs11070799

Lund, H. G. (2007). Accounting for the world's rangelands. Rangelands 29, 3-10. doi: 10.2111/1551-501X(2007)29[3:AFTWR]2.0.CO;2

Macon, D. (2020). Paying for the presence of predators: an evolving approach to compensating ranchers. Rangelands 42, 43-52. doi: 10.1016/j.rala.2020.03.001

Macon, D., Baldwin, R., Lile, D., Stackhouse, J., Rivers, C. K., Saitone, T., et al. (2018). Livestock Protection Tools for. California Ranchers. Oakland: University of California Division of Agriculture and Natural Resources. doi: 10.3733/ucanr.8598

Markus, S. (2002). Development of a Fenceless Livestock Control System Behavioural Responses of Cattle (Ph.D. dissertation). University of Alberta.

Markus, S. B., Bailey, D. W., and Jensen, D. (2014). Comparison of electric fence and a simulated fenceless control system on cattle movements. Livestock Sci. 170, 203-209. doi: 10.1016/j.livsci.2014.10.011

Mendes, E., Carstens, G., Tedeschi, L., Pinchak, W., and Friend, T. (2011). Validation of a system for monitoring feeding behavior in beef cattle. J. Anim. Sci. 89, 2904-2910. doi: 10.2527/jas.2010-3489

Miller, G., Mitchell, M., Barker, Z., Giebel, K., Codling, E., Amory, J., et al. (2020). Using animal-mounted sensor technology and machine learning to predict time-to-calving in beef and dairy cows. Animal 14, 1304-1312. doi: 10.1017/S1751731119003380

Millward, M. F., Bailey, D. W., Cibils, A. F., and Holechek, J. L. (2020). A GPS-based evaluation of factors commonly used to adjust cattle stocking rates on both extensive and mountainous rangelands. Rangelands 42, 63-71. doi: 10.1016/j.rala.2020.04.001

Mosley, J. C., Roeder, B. L., Frost, R. A., Wells, S. L., McNew, L. B., and Clark, P. E. (2020). Mitigating human conflicts with livestock guardian dogs in extensive sheep grazing systems. Rangeland Ecol. Manage. 73, 724-732. doi: 10.1016/j.rama.2020.04.009

Mueggler, W. F. (1965). Cattle distribution on steep slopes. J. Range Manag. 18, 255-257. doi: 10.2307/3895492

Neo, J. P. S., and Tan, B. H. (2017). The use of animals as a surveillance tool for monitoring environmental health hazards, human health hazards and bioterrorism. Vet. Microbiol. 203, 40-48. doi: 10.1016/j.vetmic.2017. 02.007

Nielson, R. M., and Sawyer, H. (2013). Estimating resource selection with count data. Ecol. Evol. 3, 2233-2240. doi: 10.1002/ece3.617

Norton, B. E., Barnes, M., and Teague, R. (2013). Grazing management can improve livestock distribution: increasing accessible forage and effective grazing capacity. Rangelands 35, 45-51. doi: 10.2111/RANGELANDS-D-13-00016.1

Nyamuryekung'e, S., Cibils, A. F., Estell, R. E., VanLeeuwen, D., Steele, C., Estrada, O. R., et al. (2020). Do young calves influence movement patterns of nursing Raramuri Criollo cows on rangeland? Rangeland Ecol. Manage. 73, 84-92. doi: 10.1016/j.rama.2019.08.015

Park, D., Kim, S., An, Y., and Jung, J.-Y. (2018). LiReD: a lightweight real-time fault detection system for edge computing using LSTM recurrent neural networks. Sensors 18:2110. doi: 10.3390/s180 72110

Patison, K., Trotter, M., Swain, D., Corbet, N., Bailey, D., and Kinder, J. (2017). "Applying proximity sensors to monitor beef cattle social behaviour as an indicator of animal welfare," in 1st Asian-Australasian Conference on Precision Pastures and Livestock Farming (Hamilton).

Patison, K. P., Swain, D. L., Bishop-Hurley, G. J., Robins, G., Pattison, P., and Reid, D. J. (2010). Changes in temporal and spatial associations between pairs of cattle during the process of familiarisation. Appl. Anim. Behav. Sci. 128, 10-17. doi: 10.1016/j.applanim.2010.10.001 
Pierce, C. F., Speidel, S. E., Coleman, S. J., Enns, R. M., Bailey, D. W., Medrano, J. F., et al. (2020). Genome-wide association studies of beef cow terrainuse traits using Bayesian multiple-SNP regression. Livestock Sci. 232:103900. doi: 10.1016/j.livsci.2019.103900

Pinchak, W. E., Smith, M. A., Hart, R. H., and Waggoner Jr, J. W. (1991). Beef cattle distribution patterns on foothill range. J. Range Manage. 44, 267-275. doi: $10.2307 / 4002956$

Provenza, F. D. (2008). What does it mean to be locally adapted and who cares anyway? J. Anim. Sci. 86, E271-E284. doi: 10.2527/jas.2007-0468

Reeves, M. C., and Mitchell, J. E. (2011). Extent of coterminous US rangelands: quantifying implications of differing agency perspectives. Rangeland Ecol. Manage. 64, 585-597. doi: 10.2111/REM-D-11-00035.1

Reinermann, S., Asam, S., and Kuenzer, C. (2020). Remote sensing of grassland production and management-A review. Remote Sen. 12:1949. doi: $10.3390 /$ rs12121949

Rigge, M., Smart, A., Wylie, B., and de Van Kamp, K. (2014). Detecting the influence of best management practices on vegetation near ephemeral streams with Landsat data. Rangeland Ecol. Manage. 67, 1-8. doi: 10.2111/REM-D-12-00185.1

Roath, L. R., and Krueger, W. C. (1982a). Cattle grazing and behavior on a forested range. J. Range Manage. 35, 332-338. doi: 10.2307/3898312

Roath, L. R., and Krueger, W. C. (1982b). Cattle grazing influence on a mountain riparian zone. J. Range Manage.35, 100-103. doi: 10.2307/3898531

Roche, L. M., Cutts, B. B., Derner, J. D., Lubell, M. N., and Tate, K. W. (2015). Onranch Grazing strategies: context for the rotational grazing dilemma. Rangeland Ecol. Manage. 68, 248-256. doi: 10.1016/j.rama.2015.03.011

Saint-Dizier, M., and Chastant-Maillard, S. (2015). Methods and onfarm devices to predict calving time in cattle. Vet. J. 205, 349-356. doi: 10.1016/j.tvjl.2015.05.006

Saitone, T. L., and Bruno, E. M. (2020). Cost effectiveness of livestock guardiandDogs for predator control. Wildl. Soc. Bull. 44, 101-109. doi: $10.1002 /$ wsb. 1063

Sanchez-Iborra, R., Sanchez-Gomez, J., Ballesta-Viñas, J., Cano, M.-D., and Skarmeta, A. (2018). Performance evaluation of LoRa considering scenario conditions. Sensors 18:772. doi: 10.3390/s18030772

Schlecht, E., Hülsebusch, C., Mahler, F., and Becker, K. (2004). The use of differentially corrected global positioning system to monitor activities of cattle at pasture. Appl. Anim. Behav. Sci. 85, 185-202. doi: 10.1016/j.applanim.2003.11.003

Senft, R., Rittenhouse, L., and Woodmansee, R. (1985). Factors influencing patterns of cattle grazing behavior on shortgrass steppe. J. Range Manage., 49:386-400. doi: 10.2307/3899341

Siebert, B., and Macfarlane, W. (1975). Dehydration in desert cattle and camels. Physiol. Zool. 48, 36-48. doi: 10.1086/physzool.48.1.30155636

Sowell, B., Branine, M., Bowman, J., Hubbert, M., Sherwood, H., and Quimby, W. (1999). Feeding and watering behavior of healthy and morbid steers in a commercial feedlot. J. Anim. Sci. 77, 1105-1112. doi: 10.2527/1999.7751105x

Stampa, E., Zander, K., and Hamm, U. (2020). Insights into German consumers' perceptions of virtual fencing in grassland-based Bbeef and dairy systems: recommendations for communication. Animals 10:2267. doi: 10.3390/ani10122267

Stephenson, M. B., Bailey, D. W., and Jensen, D. (2016). Association patterns of visually-observed cattle on Montana, USA foothill rangelands. Appl. Anim. Behav. Sci. 178, 7-15. doi: 10.1016/j.applanim.2016.02.007

Swanson, S. R., Wyman, S., and Evans, C. (2015). Practical grazing management to meet riparian objectives. J. Rangeland Appl. 2, 1-28.

Tanaka, J. A., Rimbey, N. R., Torell, L. A., Taylor, D. T., Bailey, D., DelCurto, T., et al. (2007). Grazing distribution: the quest for the silver bullet. Rangelands 29, 38-46. doi: 10.2111/1551-501X(2007)29[38:GDTQFT]2.0.CO;2

Tate, K. W., Atwill, E. R., McDougald, N. K., George, M. R., and Witt, D. (2000). A method for estimating cattle fecal loading on rangeland watersheds. J. Range Manage. 53, 506-510. doi: 10.2307/4003651

Theurer, M., Anderson, D., White, B., Miesner, M., Mosier, D., Coetzee, J., et al. (2013). Effect of Mannheimia haemolytica pneumonia on behavior and physiologic responses of calves during high ambient environmental temperatures. J. Anim. Sci. 91, 3917-3929. doi: 10.2527/jas.2012-5823

Thoma, D. P., Bailey, D. W., Long, D. S., Nielsen, G. A., Henry, M. P., Breneman, M. C., et al. (2002). Short-term monitoring of rangeland forage conditions with AVHRR imagery. J. Range Manage. 55, 383-389. doi: 10.2307/4003475

Thomas, M. G., Dillon, J. A., Bailey, D. W., Pierce, C. F., Speidel, S. E., and Enns, R. M. (2020). “ Grazing distribution of beef cattle: acronyms and spatial measures, “ in Mid-West Section American Society for Animal Science, Abstract 239.

Tobin, C., Bailey, D. W., Trotter, M. G., and O'Connor, L. (2020). Sensor based disease detection: A case study using accelerometers to recognize symptoms of Bovine Ephemeral Fever. Comput. Electron. Agric. 175:105605. doi: 10.1016/j.compag.2020.105605

Trotter, M. (2010). Precision agriculture for pasture, rangeland and livestock systems. Food Secur. Sustain. Agric. 15:18. doi: 10.19103/AS.2017.0032.18

Trotter, M., Lamb, D., Hinch, G., and Guppy, C. (2010). Global navigation satellite system livestock tracking: system development and data interpretation. Anim. Prod. Sci. 50, 616-623. doi: 10.1071/AN09203

Turner, L., Udal, M., Larson, B., and Shearer, S. (2000). Monitoring cattle behavior and pasture use with GPS and GIS. Can. J. Anim. Sci. 80, 405-413. doi: 10.4141/A99-093

Umstatter, C., Morgan-Davies, J., and Waterhouse, T. (2015). Cattle responses to a type of virtual fence. Rangeland Ecol. Manage. 68, 100-107. doi: 10.1016/j.rama.2014.12.004

Valentine, K. A. (1947). Distance from water as a factor in grazing capacity of rangeland J. Forest. 45, 749-754.

Vallentine, J. F. (2000). Grazing Management. San Diego, CA: Academic Press.

Van Eeden, L. M., Crowther, M. S., Dickman, C. R., Macdonald, D. W., Ripple, W. J., Ritchie, E. G., et al. (2018). Managing conflict between large carnivores and livestock. Conserv. Biol. 32, 26-34. doi: 10.1111/cobi.12959

VanWagoner, H. C., Bailey, D. W., Kress, D. D., Anderson, D. C., and Davis, K. C. (2006). Differences among beef sire breeds and relationships between terrain use and performance when daughters graze foothill rangelands as cows. Appl. Anim. Behav. Sci. 97, 105-121. doi: 10.1016/j.applanim.2005.07.005

Webber, B. L., Weber, K. T., Clark, P. E., Moffet, C. A., Ames, D. P., Taylor, J., et al. (2015). Movements of domestic sheep in the presence of livestock guardian dogs. Sheep Goat Res. J. 30 .

Wijesingha, J., Astor, T., Schulze-Brüninghoff, D., Wengert, M., and Wachendorf, M. (2020). Predicting forage quality of grasslands using UAV-borne imaging spectroscopy. Remote Sen. 12:126. doi: 10.3390/rs12010126

Williams, R. E. (1954). Modern methods of getting uniform use of ranges. J. Range Manage. 7, 77-81. doi: 10.2307/3893862

Wolfger, B., Jones, B. W., Orsel, K., and Bewley, J. M. (2017). Technical note: evaluation of an ear-attached real-time location monitoring system. J. Dairy Sci. 100, 2219-2224. doi: 10.3168/jds.201611527

Wyman, S., Bailey, D., Borman, M., Cote, S., Eisner, J., Elmore, W., et al. (2006). Riparian area management: Grazing Management Processes and Strategies For Riparian-Wetland Areas. Technical Reference 1737-20.” BLM/ST/ST-06/002+ 1737. US Department of the Interior, Bureau of Land ...).

Young, J., Draper, J. P., and Kinka, D. (2019). Spatial associations of livestock guardian dogs and domestic sheep. Hum. Wildl. Interact. 13:6.

Conflict of Interest: The authors declare that the research was conducted in the absence of any commercial or financial relationships that could be construed as a potential conflict of interest.

Copyright (C) 2021 Bailey, Trotter, Tobin and Thomas. This is an open-access article distributed under the terms of the Creative Commons Attribution License (CC BY). The use, distribution or reproduction in other forums is permitted, provided the original author(s) and the copyright owner(s) are credited and that the original publication in this journal is cited, in accordance with accepted academic practice. No use, distribution or reproduction is permitted which does not comply with these terms. 